\title{
Plotinus and Magic
}

\author{
Wendy Elgersma Helleman \\ Religious Studies and Philosophy \\ University of Jos, Nigeria, West Africa \\ w.helleman@utoronto.ca
}

\begin{abstract}
Contemporary scholarship accents incipient theurgical practice for Plotinus; this lends a certain urgency to the question of his acceptance of magic. While use of magic recorded in Porphyry's Vita Plotini has received considerable attention, far less has been done to analyze actual discussion in the Enneads. Examination of key passages brings to light the context for discussion of magic, particularly issues of sympathy, prayer, astrology and divination. Equally important is Plotinus' understanding of the cosmos and role of the heavenly bodies. Plotinus' affirmation of the highest part of the soul as undescended, together with the claim that our soul has a common origin with the World Soul in Soul-Hypostasis, is significant for the relative unimportance he attributes to the role and effect of magic.
\end{abstract}

\section{Keywords}

Plotinus, magic, soul, sympathy, astrology, divination, enchantment, prayer,

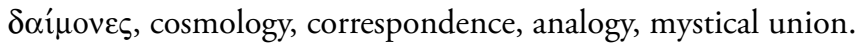

Just how did the Neoplatonists regard magic and theurgy? This topic has attracted considerable attention in the last few years. ${ }^{1}$ A number of decades have passed since A.H. Armstrong appeared to have answered successfully Merlan's thesis on Plotinus as magician. ${ }^{2}$ Significant new scholarly work on later Neoplatonists like Iamblichus has reopened the question, particularly in the effort to establish lines of continuity between

\footnotetext{
1) Shaw (1995); Rappe (2000); Mazur (2003) and (2004).

2) Merlan (1953); Armstrong (1955) 73-79; Dodds (1951). 
Plotinus and his successors. ${ }^{3}$ While it is conceded that Plotinus was no conjuror, magician, or sorcerer, the current discussion focuses on his acquaintance with, and use of theurgy, even as an incipient practice; ${ }^{4}$ scholars are now examining the Enneads for indications of thought-experimentation or meditative technique as a form of the theurgical practice popularized by his Neoplatonic successors. ${ }^{5}$

The present treatment, motivated by such questions, but also by important recent work done on the related topic of sympathy, ${ }^{6}$ cannot hope to do justice to the substantive questions regarding understanding of ritual, magic, religion and philosophy which have been raised in recent scholarly work. ${ }^{7}$ It has a more limited purpose, to address aspects of Plotinus' view of magic by examining closely passages in the Enneads where Plotinus discusses magic and related phenomena, using iv 4 [28] 30-45 from his

3) On Iamblichus, see Finamore and Dillon (2002); Finamore, (1999); and also Finamore (1998), giving a reply to Majercik (1998). See further Dillon (2007); and Dillon (2005).

4) For the relationship between theurgy and magic definitions are important; the present article will address the question of defining magic, but the definition of theurgy can be examined here only cursorily, since there does not yet appear to be a scholarly consensus on this definition. Suffice it to note that many scholars now reject the term 'magic' as applicable for theurgy; or at best they regard theurgy as higher magic, as Iamblichus presents it. With incantation and sacramental rites to attract the presence of divine power, the work of the theurgist proceeds not with the constraint which is said to characterize magic, but more like a spontaneous illumination from the gods as they convey power to the petitioner. Dillon (2007) recognizes that Iamblichus accepted a distinction between magic as a type of command, and prayer as petition directed to the gods. Yet, like magic, theurgy needs a skilled practitioner, expert in use of tokens ( $\sigma \dot{v} v \theta \eta \mu \alpha \tau \alpha)$ and formulae for invocation, as clues given by the gods. As Iamblichus explains in On the Mysteries, union with

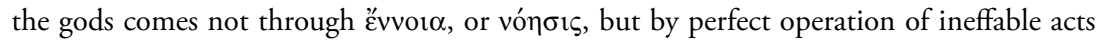

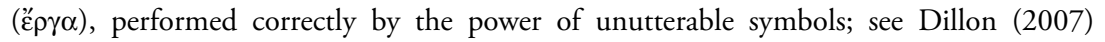
35-40.

5) Rappe (2000) initiated an interesting approach to reading Plotinus, particularly Enneads v 8, 9 where Plotinus encourages visualizing the spherical cosmos before abstracting materiality and invoking the God who made it; she regards the process as a type of theurgy (167). On the passage see also Shaw (1999) 135-137; and Mazur (2004) 45-46.

6) Pigler (2001); Gurtler (2002), reproducing almost exactly the third chapter in Gurtler (1988), a publication of interest for its discussion of the unity of treatise iv 3-5. Also of interest is Yhap (2003) on sympathy as basis of the soul's capacity for sense-perception.

7) See especially Mazur (2004) 54-55; the importance of the larger context was recognized by Smith (2004) in the chapter on religion and philosophy, 77-89. 
major treatise on the soul, as basis of discussion. ${ }^{8}$ Plotinus' involvement with magic as recorded in Porphyry's Vita Plotini is relevant, but this has already received significant attention; ${ }^{9}$ it is time to look more closely at the Enneads themselves. Such examination is necessary to provide a constructive context for re-evaluation of Plotinus' role in developments of late antiquity, as Neoplatonism moved toward a phase in which oracles and traditional rites of worship for the gods became integral to philosophy.

Because the term 'magic' is at the centre of controversy our examination will begin by developing a definition, together with some pertinent socio-historical information to help situate Plotinus in the third century religio-cultural context. Discussion of magic in the Enneads as such has to begin with some attention to terminology, from which we move on to raise a number of issues based on a reading of significant passages (which include iv 9 [8], ii 9 [33], as well as segments of iv 3-4 [27-28]), noting first the context in which Plotinus raises the issue of magic, particularly astral divination; second, the role of sympathy in explaining magic; third, the implied operative worldview, particularly the role of the heavens; fourth, the restriction of magical technique within the cosmos; and fifth, reasons why the heavenly bodies, as deities, cannot be the cause of harm or evil. The conclusion will examine briefly the relationship between Plotinus' signature position on mystical union and his understanding of magic, and consider the significance of the discussion of iv 4, 30-45 as a climax for the discussion of the soul in the entire treatise, iv 3-5.

\section{Defining Magic}

In the North American context magic is typically regarded as a rather benign enterprise, certainly when it is regarded as a form of entertainment, not a serious means of achieving desired results. However we also note a new understanding of magic which recognizes its use of hidden powers of nature, thus departing from a longstanding view of nature on a

8) For convenience of citation, unless otherwise mentioned, translations are taken from the Armstrong translation (1966-1988).

9) The Merlan/Armstrong debate focused on these issues; more recently, see Edwards (1991); Brisson (1992); also Berg (1999). For a helpful discussion that examines more closely Plotinus' views in the Enneads themselves see Wallis (1983). 
mechanical model of natural law and predictability. In some cultures magic constitutes an integral part of religion. Indeed, the anthropologists' view of magic as a primitive and manipulative form of religion is no longer prevalent. ${ }^{10}$ The contemporary African resurgent practice of traditional religion supports magic on the basis of a worldview featuring strong spiritual forces; these pervade nature, and assure unity and interdepence for all that is created. ${ }^{11}$ For the purpose of this discussion we accept the definition given in a recent survey article of magic and the occult in the Encyclopedia Britannica: a way of thinking that looks to invisible forces to influence events or effect changes in material conditions. ${ }^{12}$

10) The older consideration of magic as a primitive form of religion, such that it was characterized by manipulation of deity through specialized technique (while religion itself would establish a personal relationship characterized by spirituality, submission and prayer), represented by anthropologists such as E. B. Tylor (1832-1917), was popularized by J. Frazer's The Golden Bough (1890); it is now almost universally replaced by a definition which sees greater continuity between religion and magic, as a practice based on belief in supernatural/spiritual forces; see "Occultism," the discussion of magic (alongside alchemy, divination and witchcraft) in the New Encyclopedia Britannica: Macropaedia, especially 25.89-90 on Frazer and the anthropologists. This modern approach to magic is evident in Janowitz (2001). Focusing on the role of women in the world of magic and witchcraft, her definition of magic recognizes goals like those of religion: material gain, improving health, destroying enemies (3-4); even love rites, accordingly, are not to be relegated to magic, but may be regarded as phenomena of religion (58).

11) In an address for the World Forum on Theology and Liberation (Nairobi, Jan. 18, 2007), "Reclaiming our African Spiritual Heritage," Laurenti Magesa elaborates on the African view of the creation as one of all-pervasive divine energy, with all created beings united in intricate interrelationship, through mysterious interaction, not fully accessible to reason. Our humanity depends on universal order, and is continuous with plants and the rest of the cosmos. Power is expressed in harmony and order sustaining life. Unity of life expresses the sacred character of natural reality, and is essential to life; see Magesa (2008) especially 9-10, 12-14.

12) The article recognizes that the very definition is subject to debate, particularly with respect to the relationship between magic, religion and science. The further description recognizes magic as a practice requiring a trained magician, especially when it involves a ritual act using special objects, spells, or words with innate power, through which to influence events or conditions; see the Encyclopedia Britannica: Macropaedia article "Occultism" (25.89). Luck (1985, 3-9) gives a similar description: magic is a technique based on a belief in power located in the human soul and in the universe outside ourselves; this technique uses supersensual power and aims at imposing the human will on nature and on other human beings. Ultimately, according to Luck, magic is based on a belief in the unlimited power of the soul, which can be expressed in terms of Malinowski's term mana, 
In Greco-Roman antiquity such ritual acts, and use of specific objects or words, spells, and exclamations for magic were far more a part of everyday reality. ${ }^{13}$ Much of our evidence of magical practice comes from the Hellenistic world. Ptolemaic Egypt has been a rich source of information in the form of magical papyri. ${ }^{14}$ Aside from religio-philosophical sources like the Gnostic texts, ${ }^{15}$ Chaldean Oracles, ${ }^{16}$ or Hermetica, ${ }^{17}$ there are also signifi-

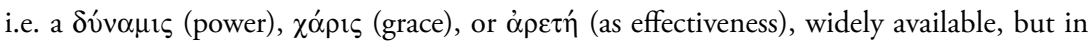

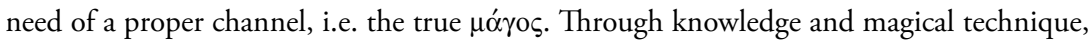

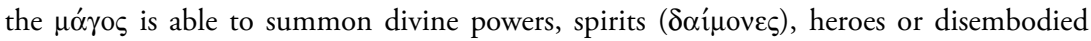
souls to work for him, to heal and help, or destroy and even to kill $(1985,3)$. Significantly Luck indicates that if magic and astrology work, it is due to an underlying belief in cosmic sympathy: the cosmos unified by chains of spiritual interconnections, similarities and correspondences (3-4). Luck recognizes that magic also uses language of petition, and does not invariably speak of compulsion $(4-5,8)$, yet the magi were less interested in pure science than in manipulating the powers $(\delta v v \alpha ́ \mu \varepsilon 1 \zeta)$ of nature, to change present circumstances, or predict and influence the future (8-9).

13) Plato's remarks in Laws 933a-e reflect on the healers, prophets and sorcerers in Athens as groups to be watched and controlled by law. Along with Medea, the ancients recognized Homeric Circe, the daughter of the Sun who could turn Odysseus' men into swine

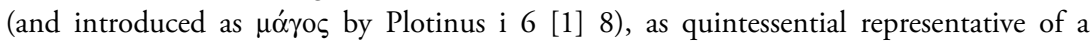
dangerous magician. An excellent introduction to magic in the ancient world is given in Dickie (2001).

14) See Betz (1992). Many of these papyri from Ptolemaic Egypt provide recipes for potions or poison ( $\varphi \alpha \dot{\rho} \mu \alpha \kappa \alpha)$ ), instructions for pose and gesture, rites and spells, methods of interpreting dreams, commands for a daimon to work in love magic, or curse tablets for victimising one's enemy (tabellae defixionum), particularly to deliver someone to underworld powers, spirits of the dead. They refer to amulets which protect against magic attack or curses, and describe gems with abbreviated formulae. Of special interest is evidence of terminology from mystery religions taken over by magical practices, referring to ritual events as $\tau \varepsilon \lambda \varepsilon \tau \alpha i$, and the magician as $\mu \nu \sigma \tau \alpha \gamma \omega \gamma o ́ s$, leading mystery candidates in initiation; on the papyri and related practices, see Janowitz (2001) 47-49, 80-81; also Dickie (2001) 27, 39-40.

15) For a basic collection of Gnostic texts see Robinson (1977). For contemporary discussion of Gnosticism and Platonism, see Turner (2001); Wallis and Bregman (1991), an excellent collection of essays; also Broek and Vermaseren (1981). For Gnostic use of magic, see the discussion of Enneads ii 9 [33] 14, below.

16) See Majercik (1989). Basic work on the Chaldean Oracles was done by Lewy (1956); its conclusions have been contested by E. R. Dodds, P. Hadot and others, but the work still provides valuable discussion.

17) Copenhaver (1992). See also the French edition of Nock and Festugière (1954-1960). 
cant literary sources like Pliny's Natural History, ${ }^{18}$ or Apuleius' Apology, his defence against accusations of using erotic magic in seducing the woman he married. ${ }^{19}$ From the major documents we realize that the magician had to be a specialist of sorts, since formulae had to be expressed and techniques carried out in a very specific manner if the rite was to succeed. The sources also testify to the largely negative reputation of magic and magicians, whether or not what we consider 'white' magic is distinguished from sorcery, or 'black' magic, practised with an intent of bring harm. ${ }^{20}$ That reputation was due in part to the secrecy on which magic thrives, as an occult art. $^{21}$

18) The Natural History (abbrev. $N H$ ) of the first century Pliny the Elder (AD 23/24-79) provides us with an excellent source of information on magic of that period; see Pliny (1940-63). Pliny recognized that the work of magi touches on ritual, healing and astrology; in these volumes he seeks to pass along the powers of herbs or roots, as secrets of past generations (NH 30.1), but also to expose lies of the magicians ( $N H 2.62$; 19.23), for he realizes that everyone is afraid of their spells $(N H 28.4)$. Although he dismisses magical cures and practices, his judgment is a little uneven by modern standards; see Janowitz, who realizes that although he regards doctors using magical recipes (along with astrological magi), as too greedy, he does not distinguish between religious and magical cure (Janowitz [2001] 13-16). Of special interest for our understanding of magic is Pliny's assessment of interconnection between parts of the natural world in terms of antipathy and sympathy (discordia, concordia, NH 20.2).

19) Apuleius of Madaura (born ca. AD 125) was accused of using love-spells; in the Apol$o g y$ (ca. AD 160) he gave a positive representation of magic, speaking of the $\mu$ ó $\gamma \circ \varsigma$ as one specializing in the best of ancient divine wisdom, handed down from holy philosophers and Persian priests versed in ceremonial law and sacred rites (Apology 25.26). On the defence, see Dickie $(2001,131,149)$, who recognizes that Apuleius was well aware of the illegality of magic, going back to the Twelve Tables (Apol. 47); also Graf (2002), especially 92-93.

20) This is recognized by Janowitz (2001) 9-12. The generally negative perception of magicians as malevolent, and magical arts as fraudulent is reflected in Plato's Symposium 202e; the effectivity of magic was typically attributed to magicians cooperating with evil powers. Janowitz reminds us that Greek literary references to the $\mu \alpha$ ó ${ }^{\circ} \varsigma$ and $\mu \alpha \gamma \varepsilon i \alpha$ are mostly

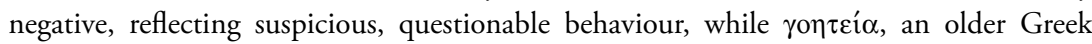
term, has even worse connotations, representing illegitimate practice, with malevolent intent (9-10). She recognizes the socially damaging nature of calling someone a magician or a witch (an attribution too often used against women), as imputing antisocial behaviour (1).

21) There is an undeniable aspect of secrecy about magic, especially on the all-important exact techniques to be applied. This has been recognized even for Pliny's record of ingredients for magical recipes; it is not enough to know what exactly has to be included in a 
Egypt, Plotinus' province of origin, had a special reputation for astrology, magic and the occult, so prima facie one could assume familiarity with magic on his part. ${ }^{22}$ His desire to pursue ancient wisdom would have reinforced that respect for magic. ${ }^{23}$ And indeed, his work reflects familiarity with magic in Gnostic and Hermetic writings. But Plotinus did the bulk of his teaching in Rome, where he was rather close to the centres of power, the senatorial class and even the emperor Gallienus. ${ }^{24}$ In Rome the attitude to magic seems to have been more negative than in the rest of the Hellenistic world, with strict laws against its use dating back to the Twelve Tables. ${ }^{25}$ Magicians and astrologers regularly faced expulsion, or

recipe-it is crucial also to know the exact amounts and specific use. On secrecy see Janowitz (2001) 14; also Dickie (2001) 27.

22) On the reputation of Egypt in this connection, see Janowitz (2001) 12; also Dickie (2001) 214, and 229-230, for appeal to Egyptian origins as a source of authority in matters of the occult. For Iamblichus' praise of the Egyptians and their theurgic rites see Gregory Shaw (1995) 3-4. Though practiced widely throughout the Hellenistic kingdoms, astrology had a special place in Ptolemaic Egypt, a source of extensive evidence of astrologers consulted for matters of business, love, or travel. And although astrology was held in a degree of respect, magic was more often denigrated as charlatan, conjuring trickery, with magicians thought to provide services with selfish or immoral aims; see Luck (1985) 3-4. From study of such a marginalized role Fritz Graf hypothesized the origin of magic alongside a philosophical moral conception of the divine, differing from that operative in $\mu \alpha \gamma \varepsilon i \alpha$; developments in science and medicine, looking at nature as matter of physical rather than divine causation, meant that the use of spells or potions ( $\dot{\varepsilon} \pi \omega \delta \alpha \dot{i}, \varphi \alpha \rho \mu \alpha \kappa \varepsilon i \alpha)$ came to be regarded as unacceptable in religious behaviour; see Graf (1996) 31-36; also Dickie (2001) 20, 22-24, 27.

23) Porphyry, Vita Plotini (abbrev. VP) 16.2.

24) Plotinus came to Rome in AD 244 and established a school, or circle for discussion, which included members of the Roman senatorial class, Orontius, Sabinillus (consul in 266), Rogatianus (who became praetor). He even counted Gallienus (emperor from 263) among his friends. From eastern parts of the empire there were adherents like Porphyry, Eustochius (from Alexandria), Serapion, Zethos, and Paulinus (from Scythopolis). See Porphyry, VP 7.7, 18-19, 29-50; and 12.1.

25) See Pliny the Elder, Natural History $(\mathrm{NH}) 30.12$, on the early law code of the Twelve Tables (dated from ca. $450 \mathrm{BC}$ ) which refers to magical incantation intending to harm crops of a neighbouring field (malum carmen incantare), as a form of ritual magic to be punished by expulsion or even death; also Janowitz (2001) 10-11, and Dickie (2001) 141-3. From the rhetor Hadrian of Tyre we know of an expert in magic burnt alive in the midsecond century AD (Dickie [2001] 148). Accusations targeted use of amulets against disease, or divination practiced in private rather than as public rite; see Janowitz (2001) 11. 
worse. ${ }^{26}$ One might expect, then, that given his socio-political enviroment Plotinus would have been sensitive to official pronouncements against magic, and this would be reflected in his treatises. Porphyry does reflect the need for caution in his reply to Iamblichus. ${ }^{27}$

\section{Terminology}

Discussion of magic in the Enneads has to begin with a consideration of the terms used, particularly $\mu \alpha \gamma \varepsilon i \alpha$, a word which dictionaries usually

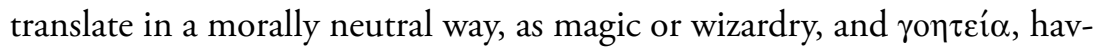
ing a stronger meaning, as sorcery or witchcraft, with intent to inflict harm. The term $\mu$ ó $\gamma$ os, Persian in origin, represented the fire-priest as wise man, able to divine the meaning of dreams and other phenomena; the

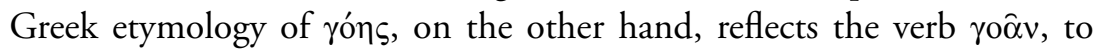
lament, thus taking us back to cries of incantation associated with magic. But by the fifth century $\mathrm{BC}$ use of these terms was virtually synonymous, as we also discover from use in Plotinus' Enneads. ${ }^{28}$

A few related terms should be noted: $\varphi \alpha ́ \rho \mu \alpha \kappa \alpha, \varphi \alpha \rho \mu \alpha \kappa \varepsilon i ́ \alpha$ and

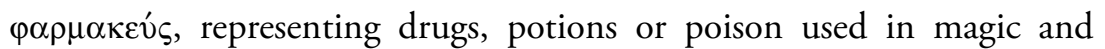
witchcraft; $\dot{\varepsilon} \pi \omega \delta$ ó $\varsigma$ as the spell or song of enchantment with which a skilled singer could charm the object of interest, and alleviate pain and suffering; attraction or enchantment is expressed as $\theta \varepsilon \dot{\lambda} \xi_{1 \zeta}$ and related

26) A number of notorious cases are illustrated in Dickie's chapter on the late Republic and early empire (2001, 142-161). Chaldean astrologers (mathematici) were expelled from Rome as magicians in $139 \mathrm{BCE}$; astrologers and magicians were also driven from Rome in $33 \mathrm{BC}$ and $\mathrm{AD}$ 16; the edict was reinstated by Vespasian in $\mathrm{AD} 69$ and Domitian in AD 89. From the reign of Tiberius, early in AD 16 after the conspiracy of Scribonius Libo Drusus, we have interesting evidence of legal cases against the working of magic and sorcery, documented in Tacitus and Dio Cassius; see Dickie (2001) 154-155. The emperor Augustus' restraining orders against seers ( $\mu$ óv $v 1 \varsigma$ ) giving prophetic utterance, especially for consultations given in secret, and predicting death, came already in AD 11. The historians attribute responsibility for Tiberius' actions against astrologers, magicians and diviners to the Pythagoreanizing Platonist Thrasyllus, who joined Tiberius' household; see Dio Cassius 49.43.5, and 57.15.8-9; also Dickie (2001) 195-6.

27) Andrew Smith gives the warning in his fragment 289 from the De Regressu Animae (found in Augustine, De Civitate Dei 10.9); the fragment is discussed in Dickie (2001) 206-207.

28) For a helpful discussion of the basic terms, see Dickie (2001) 12-16. 


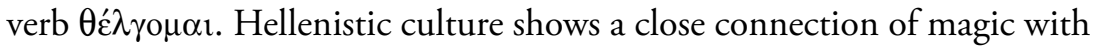
$\mu \alpha v \tau \varepsilon i \alpha$, divination, particularly divination based on astrology, although the Enneads also refer to traditional Roman augury based on the flight of birds. ${ }^{29}$ The seer, $\mu$ óv $\tau 1 \varsigma$, was recognized for his skill (or $\left.\tau \varepsilon ́ \chi v \eta\right)$, in studying the position and arrangement of the stars, or reading horoscopes; the term $\tau \varepsilon ́ \chi \vee \eta$ is also used for the practice of magic.

\section{Magic in the Enneads}

Examination of significant passages referring to magic shows us that with the exception of ii 9 [33] 14 Plotinus pays little attention to the actual practice of magic. But the discussion of magic reveals some surprising combinations of interest. On the operation of magic Plotinus refers especially to analogies with music of the lyre, or the dance. He is clearly aware also of a traditional connection of magic with healing arts. Considerable attention is given to magic in the context of divination, astrology and astral determinism; reference to spells and incantations also leads him to discuss prayer. For the most part he assumes that magic works, in much the same way that prayer and astrology work; in fact much of Plotinus' analysis reflects on the reasons why it works, and in the context of astral divination he is particularly concerned with damage control. Yet, with one of the earliest references to magic in the discussion of the unity of the

29) Magic shares a worldview with astrology, as it observes heavenly bodies for influences on the earth. Persian/Babylonian roots of the term $\mu$ ó $\gamma$ o a form of astral religion and divination, and the oldest of the occult sciences practiced by the group commonly identified as Chaldean, who represent a priestly society specialized in observation of the stars and heavenly bodies, using a complex mathematics to establish calendars and dates. The term 'Chaldean' continued to be used for experts in astrology even among the Assyrians who conquered the Babylonians; see Luck (1985) 309. Marilynn Lawrence (2005) defines astrology loosely as a method of correspondences between celestial events and activity in the human realm; see the "Introduction" of her excellent website article "Hellenistic Astrology". Based on the position, arrangement and mutual relationship of celestial bodies, astrology seeks information about future events, the success of plans, and outcome of catastrophes, illness, or famine. Magic, like astrology, considers life on two levels, with (human) life on earth as a microcosm in relationship with macrocosmic sphere of celestial phenomena; magic also shares with astrology an acceptance of the laws of cosmic sympathy, and correspondence between events in the heavens and on the earth. See further the sections of this paper, on sympathy and cosmology below. 
soul, iv 9 [8] 3.1-9 he rather casually alludes to the ability of magic to draw people together into shared feelings or experience, as confirmation of the soul's unity and sympathy.

II 9 [33] 14. In the context of strong argumentation against Gnostics, especially for considering the World Soul as source of evil, we find a remarkable passage which provides a rich source of vocabulary of magic,

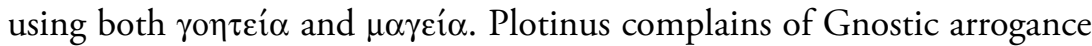

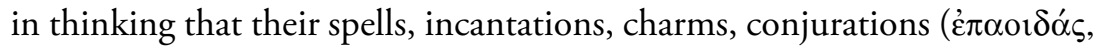

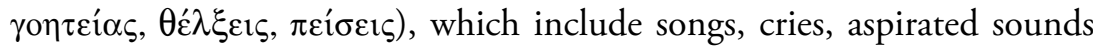

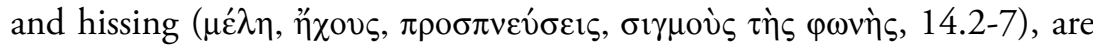
actually able to make an impact on incorporeal divine beings, as higher powers; $;^{30}$ in so doing they diminish the majesty of these divine powers. He does note demands of saying just the right thing and in the right way,

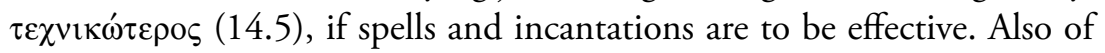
interest is the immediately following discussion of exorcism practiced by Gnostics, particularly in the cure of disease, as they seek to drive out $\delta \alpha i$ inoves, the evil spirits thought to be responsible for disease. ${ }^{31}$ Plotinus disagrees with Gnostics on the point, and advises them to practice right

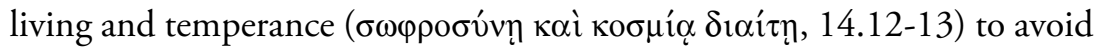
disease.

IV 3-4 [27-28]. The most specific and extended discussion of magic, asking how the effectiveness of $\gamma$ on $\tau \varepsilon^{i} \alpha$ or $\mu \alpha \gamma \varepsilon i$ can be explained, occurs in the final chapters, $40-45$ of iv 4 . The context is a discussion of the soul's memory, with the specific goal of determining whether the stars, as they hear our prayers, also have memory, as is implied by a delay between the request and the appropriate answer. ${ }^{32}$ May we think that the heavenly

\footnotetext{
30) Plotinus complains of Gnostic pretension to influence higher power with the bonds of

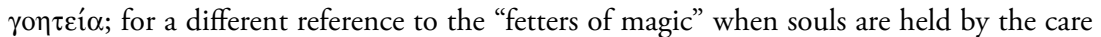
for the bodily nature, see iv 3 [27] 19.23-28, giving the metaphor of the steersman in the storm.

31) On exorcism as an important aspect of magical practice in antiquity, using an oath to expel the $\delta \alpha i ́ \mu \omega v$ thought to possess a person, causing disease or madness, see Janowitz (2001) 40-42.

32) As was noted by John Rist in his discussion of prayer (1967, 200-201), Plato had already drawn a connection between magic and prayer in Laws 909b, where he speaks of those who try to persuade the gods by illegitimate, magical use of sacrifice, prayer and incantation, like evildoers who make the god connive in crime. In the Enneads too, we note a rather low appreciation of prayer, as at iii 2 [47] 8.24-25, and 36-38, where Plotinus
} 
bodies act intentionally in making such a response? The underlying concern is that the heavenly bodies would be regarded as source or accomplice in evil, whether in temple-thievery, effeminate behaviour, slave-dealing, or acts motivated by jealousy and characterized by violence (iv 4, 31.43-55; also 39.24). This is a conclusion Plotinus wants to avoid (30.7-8); accordingly, he points to a different underlying cause for such

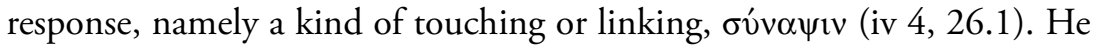
also appeals to the sympathetic interconnection of all things in our universe; answered prayer is not to be attributed to wilful intention on the part of heavenly beings. ${ }^{33}$ Benefits flow naturally from the All to the particular. But if something bad occurs it must be attributed to the inability of the substrate to receive these transmissions (iv 4, 38.3-10). If stars hear our prayer and respond to it, these results come in a sort of automatic way (iv 4, 39.17-18). Sympathy, in turn, is illustrated from examples of music, playing the lyre and a dance performance (iv 4, 33.7-25; also iii 2 [47] 16. 25-27). Music is not only an illustration of sympathy, but may itself be regarded as a form of magic; Plotinus speaks of the soul drawn by

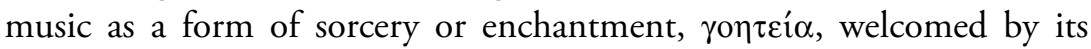
unreasoning part (iv $4,40.22-28$ ). And he is aware of the positive role of

speaks of the soldier with inadequate military training, who would be better off to equip himself and fight courageously, rather than praying to a god; similarly the farmer who wants a harvest should look after his fields, not just rely on prayer, while expecting nature to provide the impossible (8.38-42). Nor should evil men expect others to sacrifice themselves to answer their prayers, or expect the gods to go out of their way to look after their wicked concerns (iii 2, 9.10-17); such prayers upset the providential order of the cosmos (see also Rist [1967] 208-9). With Plato (Laws 801a), Plotinus regarded the gods as taking an interest in human affairs and hearing prayers. They could be expected to reward justice and virtue, and to punish injustice (as at iii 2, 9.9-10: $\alpha \gamma \alpha \theta 0 i ̂$... $\alpha \gamma \alpha \theta$ òv ßíov, a theme developed in iv 4, 25 and 26), but one should not expect prayers to bend the will of the gods, On this topic see also Dillon (2002).

33) Magic is directed to such linking of all things in much the same way as prayer; magical results also are effected by powers which are in accord with sympathy in the universe, iv 4, 26.1-4; Plotinus makes a similar point at 38.3-10, and 40.22-28, that response to prayer or magical/ritual incantation is not to be attributed to a specific cause, implying specific intention, but because beneficial results are characteristic of transmissions from the All, while the bad are due to inability of substrate to receive such. Plotinus does affirm prayers heard by stars $(30,1 \mathrm{ff}$.$) , so the issue involves astrology, as well as memory. The role of$ sympathy, and sympathetic interaction of all parts of the cosmos, as an organic unity, is important in explaining prayer, magic and divination by astrology. 


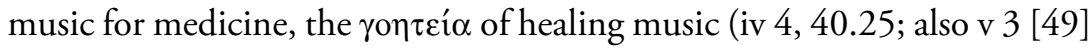
17.18-20, on which see below). ${ }^{34}$

A few other passages can be noted for brief allusion to magic: iv 9 [8] 3.1-9; v 3 [49] 17.18-20; and vi 6 [34] 18.48. One of the more interesting contexts for the discussion of magic is its role in Nature, introduced at iv 9 [8] 3.3 with a brief allusion to nature as the force drawing all things together and intertwining them in love, thus recalling the role of Eros in Plato's Symposium. ${ }^{35}$ The theme is elaborated in iv 4, 40-45, where Plotinus goes so far as to speak of Eros as the true $\varphi \alpha \rho \mu \alpha \kappa \varepsilon v ́ s$ and source of the magic arts of love (40.10), drawing all things together; his point here is to indicate that spell-binding and enchantment characterizes nature-it is not a matter of $\tau \varepsilon^{\prime} \chi v \eta$; those who are specialized in the magic arts have discovered the secrets of nature, and are simply making use of what is already implanted in nature (40.5-9).

The theme of magical attraction was introduced already in iv 3 [27] 12, in the discussion of embodiment of souls, a process illustrated with the mythical account of Dionysus who was drawn to his destruction with a mirror. For Dionysus such attraction was ominous; but in general, when Plotinus speaks of souls attracted to their reflection in the visible world and descending by the power of magic, as it were, such descent has to be understood in the same way that Plotinus usually understands embodiment, whether as a natural process, a matter of necessity, or as a culpable fall of the soul. ${ }^{36}$ The theme of bewitchment of souls occurs in a clearly negative sense at v 1 [10] 2.13 where he refers to souls being deceived when bewitched; also at i 4 [46] 9.1-2, Plotinus compares being overcome by magic arts as an illness; and at ii.3 [52] 15.13-17, he speaks of souls

\footnotetext{
34) Plato's Euthydemus 289e4-290a3 speaks of incantations to charm vipers, scorpions and cure illnesses. Asclepius was known to use gentle singing ( $\left.\dot{\varepsilon} \pi \omega \delta \delta_{\varsigma}\right)$ ), together with potions and antidote drugs ( $\varphi \alpha \dot{\rho} \mu \alpha \kappa \alpha$ ), and even Galen allowed for incantations; on music as a form of magic in healing, see Dickie (2001) 24-25.

35) Symposium 203d; for an excellent discussion of the theme from Plato, adapted by Plotinus and elaborated in the Renaissance by Ficino, see Hadot (1982).

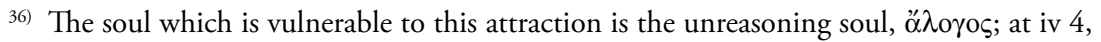

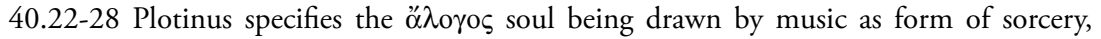

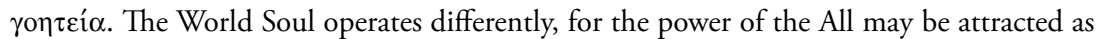
if by magic to a specific part, even in response to a petitioner, but the All gives of itself spontaneously, and is not itself affected (4, 42.13-20).
} 
born under external circumstances as victims and, as it were, under enchantment.

Yet enchantment does not always have such a negative sense, as for example at v 3 [49] 17.18-20, where Plotinus speaks of the magic of chanting to draw the soul on toward union with the One, comparing such a song with that used to soothe the birth pangs of maternal labour. Similarly in vi 6 [34] 18.48 Plotinus speaks of the beauty of real being ( $\tau$ ò ôv) having the power of enchantment, $\theta \varepsilon \dot{\lambda} \gamma \varepsilon \varepsilon v$, so that all that depends on it is happy to receive a trace. In iv 4.43 he affirms that the wise man, as $\lambda$ orıкós, will be in control of the situation, and not affected by such

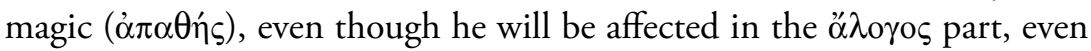
to the point of suffering disease or death, just as $\delta \alpha i$ inoves in their unreasoning aspect may be affected by magic. And he concludes this general discussion with a rather surprising generalization, that the entire life of those oriented to the practical life $\left(\pi \rho \hat{\alpha} \xi_{1 \zeta}\right)$ is one of bewitchment, as they are drawn along, fascinated by nature as master magician (43.16-23; 44.18-27). Everything that looks to another, an external principle, is under spell to it; freedom from magic comes only through contemplation $\left(\theta \varepsilon \omega p^{\prime} \alpha\right)$, and maintaining oneself intent on oneself in contemplation (44.1, 18; and 33-37).

These are some of the more significant passages in which Plotinus discusses or alludes to the practice of magic. It is important to begin by recognizing such discussion in context, particularly to discover how Plotinus interweaves treatment of magic with other topics, whether the effect of music, divination, the arts of love, astrology, prayer or healing. Although some of these associations are surprising, certainly from a modern perspective, careful attention to these matters is essential for recognizing patterns of argumentation with respect to magic.

\section{The Role of Sympathy for Magic}

It is important, as a second point, to note extensive use of principles also operative in theurgy and magic, namely, sympathy and correspondence. ${ }^{37}$

\footnotetext{
37) As noted above (note 29) sympathy was already well-established as a significant aspect of astronomy and astrology from its origins with the Chaldeans or Babylonians, based on a worldview which predates our modern mechanical view of the world in terms of natural
} 
Sympathy represents a community of experience or feeling, based on likeness or affinity, and serves to assure cohesion of the universe especially on a horizontal plane, where parts of the universe interact with one another (as at iv 9 [8] 3.1-9). Plotinus also applies it vertically, between higher and lower beings (iv 4 [28] 39.6-14; and iii 3 [48] 2 and 6.23). Sympathy represents the common denominator in his explanations of magic, prayer and divination, whether by augury or astrology. Certainly his understanding of sympathy reveals strong roots in a Stoic understanding of the universe as a living organism, in which all parts cooperate toward a common goal, guided by the divine $\lambda$ ó $\gamma$ ○ $\varsigma$ as the primary active agent, holding everything together on the macrocosmic level as a World Soul. ${ }^{38}$ But unlike the Stoics, Plotinus accepted a transcendent source and cause of sympathy in the one immaterial soul, the source of both the soul of the world and our souls, and the final explanation of unity in the cosmos (iv 9, 3.1-9; iv $3,1-8) .{ }^{39}$ So the challenge for Plotinus was to 'dematerialize' the Stoic theme of sympathy in the cosmos with a transcendent source.

law and predictability of cause and effect; magic and astrology takes us back to a world of invisible powers, mystical forces at work in our world. But unlike the present understanding of the universe, the cosmos was regarded as a unified reality, with universal and individual, or macrocosmic and microcosmic entities in correspondence or harmony with one another. See Lawrence (2005) 3 b iii.

38) The Stoic background of Plotinus' understanding of sympathy is the focus of Pigler (2001), where she discusses Plotinus' debt to Stoic materialist and progressive understanding of the universe as universal Nature, and examines how, in his use of sympathy, Plotinus 'dematerializes' the Stoic organic cosmology to develop a transcendent perspective. For Stoics cohesion and permanence was given by $\pi v \varepsilon \hat{v} \mu \alpha$, a corporeal soul as principle of organization, and the important constituent in tension ( $\tau$ óvo $\varsigma$ ) of all things. It was repre-

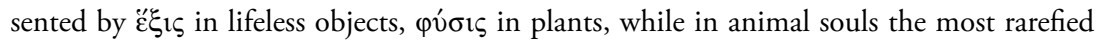
$\pi v \varepsilon \hat{v} \mu \alpha$ permeated the body, allowing for sensation and thought. It was concentrated in

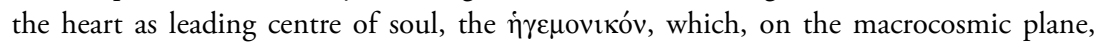
Posidonius located in the heavens (Pigler [2001] 49-50); also Wilberding (2006) 37. Gurtler (2002) provides a chronological survey of passages in the Enneads on sympathy, beginning with the earliest discussions like iii 1 [3] 4 and 7, focusing on Plotinus' adaptation of Stoic understanding of the cosmos as a living organic unity, in which all parts interact with each other.

39) Gurtler (2002) 252-3, recognizes the contribution of iv 3-4 [27-28] for the discussion of sympathy and magic, clarifying the role of cosmic sympathy in the relationship between the World Soul and individual soul, as it affects the embodied soul as part of the universe as a whole living being. Sympathy links the various parts of the universe, and is important in assuring the unity of the universe; it is rooted in soul, and ultimately in the unity of the 
Soul, as basis of life and mutual interaction of the parts of our world, represents the intelligible world as it is imaged in bodily reality through a hierarchy of $\lambda$ óyor (vi 4 [22] 3.1-22. In this process bodily reality is limited in receiving the forms, and soul finds a need of establishing sympathy with body, as basis of sense-perception. ${ }^{40}$ But the soul experiences evil when it becomes too sympathetic with body; see i 2 [9] 3.13 and $6.25-27$, on the soul being altogether o $\mu$ o $\alpha$ $\alpha$ ńs with body, which is inferior ( $\chi \varepsilon i p \omega v)$, forgetting to turn back to the world above; see also ii 3 [52] 13.34-47 on the weakness of body hindering work of the soul.

The development of this theme is reminiscent of the magic of attraction in the universe. If soul is to do its work of developing the cosmos it must remain in contact with its own source in noetic being. This is one important reason why Plotinus emphasizes that even the fallen soul is not altogether out of touch with the higher world, though it may not be conscious of that connection; with the higher part of the soul we remain undescended and $\dot{\alpha} \pi \alpha \theta \dot{\eta} \varsigma$, and therefore immune to the effects of magic. As higher beings the heavenly bodies are more perfect; they have a greater share in unity and sympathetic interaction, represented by the dance as an illustration of harmony of movement (iv 4 [28] 8.46-61). ${ }^{41}$

In his explanation of magic and divination, thus, Plotinus accepts a significant role for sympathy, but seeks to evade the consequences of astrological determinism, which he considers inevitable for those who accept only a material cosmos. ${ }^{42}$ Sympathy operates only within the world

intelligibles and the One. One of the more important passages on sympathy, iv 4 [28] 32.5-39, discusses the single living being encompassing all living beings, with soul extending to all its parts (Gurtler [2002] 256).

40) On the significance of sympathy for knowledge and sense-perception see Yhap (2003).

41) The 'symphony' of heavenly bodies is also represented by the metaphor of the lyre, in sympathy with itself, and naturally in tune, with its strings also in sympathy with one another (i.e. making one sound together) when plucked ( $\sigma v \mu \pi \alpha \theta \dot{\eta} \varsigma$, iv 4, 8.52-61).

42) Plotinus also uses the metaphor of the dance in iv 4 [28] 33 and 34, especially 33.7-26, as he elaborates on the heavenly bodies, moving according to reason, and influencing terrestrial phenomena in a relationship marked by sympathy. In this discussion he aims at undermining determinism, as also iii 3 [48] 6 and iii 1 [3] 8-10. The role of the stars, explained by sympathy and correspondence, is once more discussed in the late treatise ii 3 [52], where Plotinus returns to the interweaving of causal factors in the unity of the universe as whole; sympathy of shared feeling is based on correspondence, allowing for a single melody (ii 3, 2-7; and 12.29-32, although we note that editors recognize the final 
of bodily reality. Plotinus insists that our ability for (self-) control and reason (as that which is truly 'ours') means that we cannot be subject to the powers which are restricted to cosmic interaction. And magic is clearly limited in operation to the interconnections characteristic of the embodied cosmos.

\section{Cosmology and Correspondence}

To understand magic and sympathy it is important to recognize the worldview with which Plotinus was operating, and the principle of correspondence which allowed for understanding the heavens on the human analogy. Plotinus clearly accepted the Ptolemaic view of the earth as spherical, suspended at the centre of a series of spheres, beginning with that of the moon and sun, as well as the five planets, beyond which were the spheres of the fixed stars. ${ }^{43}$ With Plato, Plotinus recognized that the stars were ensouled, and from the Timaeus $42 \mathrm{~d}$-e accepted the role of younger (planetary) gods in steering the souls for their descent to embodiment. ${ }^{44}$ With the Stoics, Plotinus adapted the Platonic view of the World

comment as the conclusion of a gloss, from 12.12-32). Both magic and prayer work because of the sympathy or $\sigma u \mu \varphi \omega v i \alpha$ of all things drawn together as by $\varphi \imath \lambda i^{\prime} \alpha$ (iv 4 , 40.1-9); on this theme see also Gurtler (2002) 245, 258-259.

43) Plotinus' discussion of magic reflects understanding of the universe as a triadic hierarchy, yet unlike the Homeric, mythical three-tiered structure, with the heavens above, the earth in the middle, and underworld beneath (Janowitz [2001] 30). By the third century $\mathrm{BC}$ a new view emerged, with the earth as sphere suspended in a multi-layered cosmos. For most ancient philosophers the earth was regarded as the stable center and hearth of all reality, while the sun and fixed stars moved around them. Aristotle's cosmology was refined by Claudius Ptolemy of Alexandria (fl. AD 130-150) to match current astronomical observations. See Lawrence (2005) 4 d.

44) Plato showed some interest in astral phenomena, and awareness of divination by stars or portents from celestial bodies (Timaeus 40c-d), but gave preference to divination by

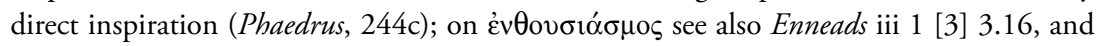
Lawrence (2005) 2 c. On ensoulment of celestial bodies see also Phaedrus 245c. On more than one occasion Plotinus refers to Plato's Myth of Er (Republic 10.614-621), with the Spindle of Necessity holding together the cosmos; its axis holds the spheres of fixed stars and planets, while the three Fates ( $\mu$ oípal) help turn the wheel (ii 3 [52], 9.1-7 and 15.117; iv 4 [28] 31.25-28; iii 2 [47], 7.20; iii 4 [15] 5.25). On Aristotle's acceptance of influence from the heavenly bodies on life on earth, together with a theory of sympathy and antipathy, see Luck (1985) 13. 
Soul (from the account of its creation in the Timaeus, as two rings, respectively composed of the 'same' and the 'other') ${ }^{45}$ to designate the celestial bodies as representatives of the World Soul and 'command-centre' of the universe. ${ }^{46}$ Via Posidonius and Middle Platonists Plotinus took note of astral determinism, and accepted a limited influence from celestial bodies on the earth, particularly for its cycles of vegetation and regional characteristics. ${ }^{47}$

With Aristotle, Plotinus recognized a significant distinction between the sub-lunary world of pv́øıs, as a world of embodiment, change, and motion, and the supra-lunary spheres with its heavenly circuit or $\pi \varepsilon \rho 1 \varphi о \rho \alpha ́$, characterized by greater purity and constancy; ${ }^{48}$ the former he

45) Of the two rings with which Tim. 35a-36d presents the World Soul, the outer of the 'same' bears the stars westward, while the inner of the 'other' carries the moon, the sun and five planets eastward (allowing for no void outside). The Demiurge, looking to the eternal living being, creates our world as its copy, an image of the eternal intelligible prototype, but made of discordant elements which he attempts to mold and re-make, on the transcendent model, using mathematical proportions to mediate the intelligible in the sensible, creating the soul of being, the same and the other, again elements mediating between the intelligible and the sensible. Of the four elements assigned locations in four concentric strata, earth is at centre, given a cube shape to symbolize its stability; next, water, with animals who swim; air, with birds; and fire characterizing the heavenly bodies, which is also the locale of the race of the gods, endowed with intelligence and soul (Tim. 31b-32c); on these passages see Wilberding (2006) 8-12.

46) For Stoics $\tau$ ò $\pi \hat{\alpha} v$ indicates the universe and the void beyond it, into which the entire cosmos is resolved by fire in the periodic conflagration; $\tau$ ò ö $\lambda$ ov represents the cosmos

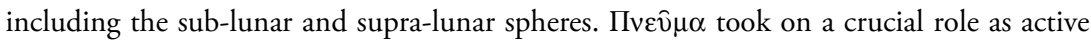
agent, permeating and uniting the cosmos as its soul, but the celestial bodies represent the

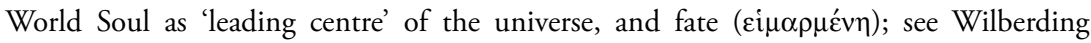
(2006) 34-38; also Pigler (2001) 48-50.

47) Discussion in ii 3 and other passages shows that Plato's Republic 10 also influences his views on our receiving character $(\eta \eta \eta \eta)$, characteristic actions $(\pi \rho \alpha \dot{\xi} \xi \varepsilon \varsigma)$ and emotions ( $\pi \dot{\alpha} \theta \eta$ ) from the stars (see note 44 above).

48) Aristotle was important in reinforcing this distinction, though Plato's reference to the

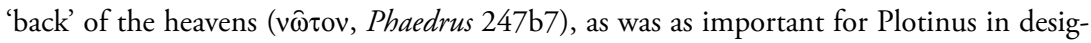
nating the point of demarcation between the material cosmos and the intelligible world, above the stars. After death souls return to the ovjpovós, above the moon (as at Phaedo 81d and Timaeus 41d ff.); on the significance of these passages for Neoplatonists see Smith (1974) 61. While Plato recognized circular motion as natural for soul in the heavens Aristotle assigned a fifth element, $\alpha i \theta \dot{n} \rho$, to motivate circular motion beyond the sphere of the moon in the highest heavens; as ultimate cause of all motion he posited an immaterial 


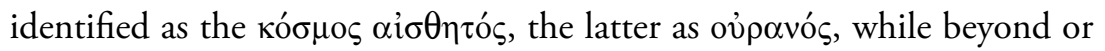

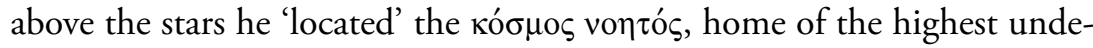
scended part of he soul. ${ }^{49} \mathrm{He}$ did not accept the double World Soul posited first by Plato (Laws 10.896ff.), accepted by Plutarch (with a malevolent irrational sub-lunar soul, and beneficent supra-lunar soul), ${ }^{50}$ and by Numenius as well; nor did he accept the view characteristic of Gnostic and Hermetic texts, with 'administrator' gods ruling the planets as malevolent 'gate-keepers', opposing the soul in its attempt to ascend to the heavens. ${ }^{51}$

prime mover, pure actuality (or self-thinking intellect), motivating the concentric celestial spheres, from the outermost spheres of fixed stars, to the innermost of the planets, through a magnet-like type of desire. On the microcosmic plane, Aristotle posited $\pi v \varepsilon v \hat{\mu \alpha} \alpha$ as a fifth element, superior to the body (composed of the well-known four elements), with a special affinity for the soul; see Wilberding (2006) 22-29.

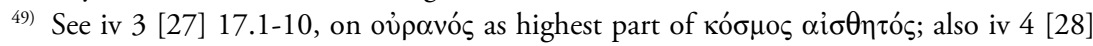
5.11-26. In the latter passage Plotinus recognizes memory as operative first when the soul

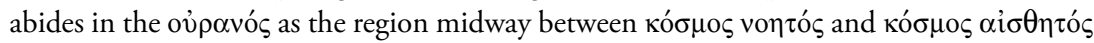
(iv 4, 5.14 and 26), as the region where stars rule their bodies easily, without concern or deliberation (iv 4, 6.10-14; iii 4 [15] 6.19-30). He reflects on oủpavó the descent of souls from noetic realm coming first to the ovjpavós, as the highest and best

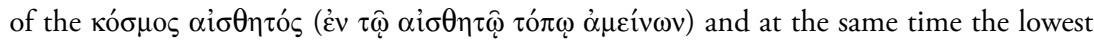

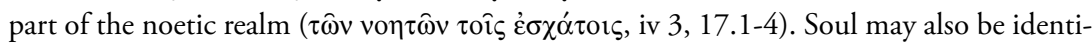
fied as 'outside' the visible cosmos, as are those said to have transcended the $\delta \alpha 1 \mu$ ovíav

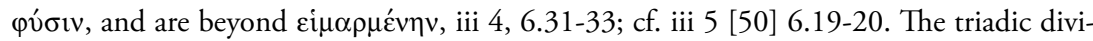
sion of the world is also given in iv 8 [6] 4.3-22; here Plotinus distinguishes the soul oper-

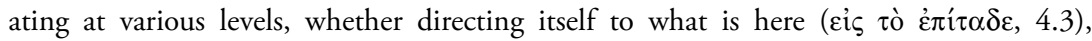

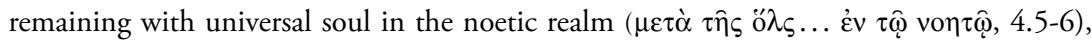

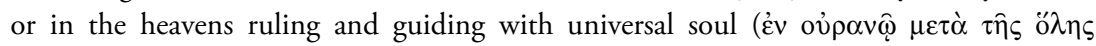

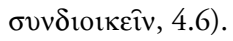

50) See Plutarch, De E apud Delphos, 393a.

51) On Plotinus and Gnostic magic, see Dickie (2001) 208. Both Gnostic and Hermetic texts reveal a worldview characterized by considerable interest in astrology, recognizing limitations on the soul imposed by the planets and celestial entities who are regarded as malevolent, so that the soul has to be set free from their power; humans are mortal, sharing in the nature of the planets and the cosmos, but also immortal, belonging with the celestial deities, to whom the soul must ascend. According to the Poimandres, a minor demiurgic figure has created seven administrators (for the planets), who govern by fate

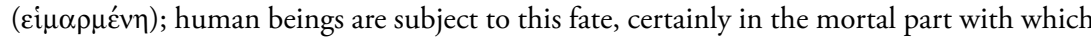
they have been endowed through their share in the planets from birth. Those who realize the divine intellectual self will ascend, and surrender qualities accumulated during descent, beginning with the body and their character traits (each to the planet associated with that 
Plotinus likewise resisted the proliferation of $\delta \alpha^{\prime} \mu \operatorname{sve}_{\varepsilon}$ in the sublunar sphere, as characteristic of Middle Platonists Plutarch ${ }^{52}$ and Apuleius, ${ }^{53}$ who present $\delta \alpha$ ímoves having emotions and a rational mind (unlike the gods), functioning as messengers between humans and gods, and respon-

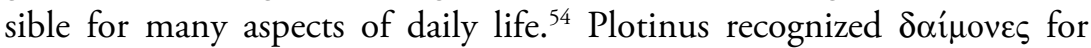
their role as a personal guardian spirit representing the leading function of the soul, and responsible for the destiny of the soul at death; $;{ }^{55}$ these

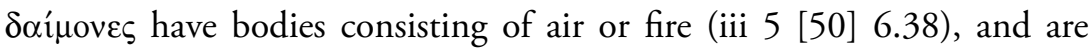
eternal like the gods, but unlike them are subject to passion; thus they

trait), until they are fit for deified life in the highest sphere. At the same time, we note the prevalence of microcosmic/macrocosmic thinking in the Poimandres (I, 12, 31; XI, 15). Man is called a 'cosmos' because of his divine composition (Asclepius 10).

52) Plutarch, De Isis 25-26, and De defectu, 10-21; on this issue see Janowitz (2001) 32-33.

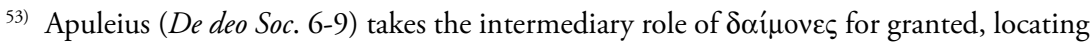
them in the air between highest ether and earth, with bodies composed of air or fire (De deo Soc. 11; also Porphyry, De abstinentia, II.39); on the significance of $\delta \alpha$ ínove $\varsigma$ see further Luck (1985) 40-41, and Janowitz (2001) 33-34.

54) For discussion of the important role of $\delta \alpha i$ inoves in the sub-lunary sphere, their pervasive presence in first centuries $\mathrm{AD}$ as helpers or messengers, intervening on behalf of humans, and responsible for vicissitudes of daily life, see Janowitz (2001) 32-33. In $\delta \alpha i$ inoves some recognized souls of the dead, especially souls of those who died unjustly;

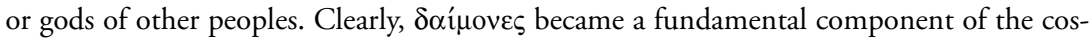
mic hierarchy, the ladder from mortality to pure divinity through purification. Plato gave a very specific description of the $\delta \alpha i \mu \omega v$ Eros as an intermediate divine power (Symp. 202d-203a); and the pseudo-Platonic Epinomis is noted for its hierarchy of gods and $\delta \alpha i \mu$ oves (984ef). Even the soul in the body might be called a $\delta \alpha i \mu \omega v$, as was the genius of Socrates; or the $\delta \alpha i \mu \omega v$ might be regarded as altogether free of the body, flying about with wings like angels (Apuleius, De deo Soc. 7-9). In the pre-Christian context they were not usually identified as evil disruptive forces; see Janowitz (2001) 34-35, and also Luck (1985) 163-164.

55) In his article on the treatise iii 4 [15] "On our allotted guardian spirit", M. Lepajoe (1998) argues that Plotinus does justice to the double tradition inherited from Plato, regarding the $\delta \alpha i \mu \omega v$ as a spiritual being, midway between gods and human beings (as at Symposium 202de), or on the other hand, as the leading part of soul, to guide and control the destiny of the soul after death and raise it to the heavens (as at Timaeus 90a and Republic 10). Asking whether the allotted $\delta \alpha i \mu \omega v$ might be a god Plotinus emphasizes that the

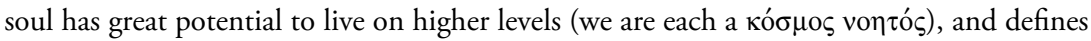
the $\delta \alpha i ́ \mu \omega v$ as the ability immediately above that operative in the soul. For the sensuous soul that would be the intellectual soul (iii 4, 3). 
can be affected by magic (iv 4 [28] 43.12). ${ }^{56}$ Plotinus firmly rejected the Gnostic view of malevolent $\delta \alpha i ́ \mu o v \varepsilon \varsigma$ responsible for disease (ii 9, 14.14); he was inclined to attribute divine status to them, as also to the planets, by virtue of the nature of soul (iii 5, 6; ii 3, 9.45-47; iv 8 [6] 5.26).

Magic and astrology operate with analogy, or correspondence between the macrocosmic world of the heavens and microcosmic world of human being on earth. ${ }^{57}$ Astrological divination was based on a correlation of events in the heavens with those on earth, using the arrangements of the stars, or pattern of birds in flight as omens, to read the intentions of the gods. Such thinking was accented in Stoic philosophy, ${ }^{58}$ but was not new,

56) Plotinus realizes that if $\delta \alpha i$ inoves can be affected by magic, they can be actively employed for magic (cf. iv 4 [28] 30.30, where he asks whether the entire heavens can be

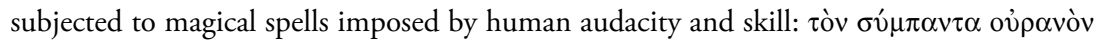

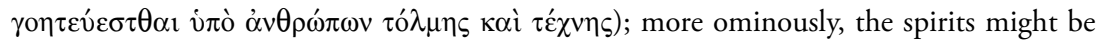

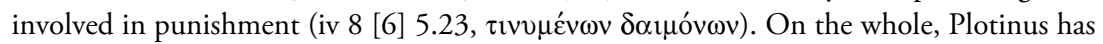
a positive view of $\delta \alpha$ ímoves, as he does of the stars and planets, arguing that they are not to be regarded as malevolent; after all, why should they wish to punish us? Further discus-

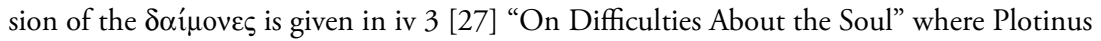

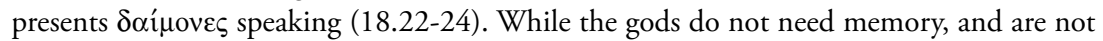
subject to affections ( $\dot{\alpha} \pi \alpha \theta \dot{\eta} \varsigma)$ or time (غ่v $\dot{\alpha} \chi \rho \operatorname{cov} \omega$, iv 3, 25.12-14), souls belong with the 'sameness' of eternity, but when embodied are subject to affections characterized by the 'otherness' of time (iv 4 [28] 17.5).

57) Understanding our earth at the centre of the cosmic planetary system, Ptolemaic mathematicians developed an extensive system of correspondences between the macrocosm and the microcosm; the discussion of Lawrence (2005, 4 a) is helpful. The term $\mu$ кроко́ $\sigma \mu о \varsigma$ is used in Aristotle's Physics 252b26, where he argues that if animals, as living beings, can move themselves, why should not the cosmos also move itself, since it is alive? Such argumentation is more widely used by Philo of Alexandria, as in Legum allegoria (I, 29, 91-92), on God ruling the cosmos as the mind rules the body; humans are understood as the world on a small scale, while the cosmos is a large-scale human being; for use of the term

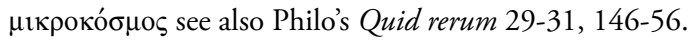

58) Pigler $(2001,51)$ indicates that Plotinus has taken over from Stoics the analogy of the visible cosmos as a living whole, an organism in which all parts, as living beings, partake of soul, cooperate, and are united by mutual sympathy; this correspondence is based in astronomical regularity, as witness to the unity and reciprocal solidarity of all cosmic parts or members (Pigler [2001] 50). Stoic thinkers, particularly Chrysippus and Posidonius, who accepted astral divination, also regarded the universe as a macrocosmic ensouled, reasonable and intelligent being, on the analogy of the microcosmic human living being (Stoicorum Veterum Fragmenta, 2.1192; and Cicero, On Divination ii 42). Like Aristotle, and Plato in the Timaeus, the Stoics spoke of the universe as a "large animal" ( $\left.\mu \varepsilon_{\gamma} \gamma \zeta \zeta_{\mathrm{\varphi}} \mathrm{ov}\right)$. 
for one can find arguments based on correspondence in Pythagoras and Plato (Philebus, Republic, Timaeus)..$^{59}$ In arguing for the role of the World Soul as source of motion in the universe, for example, Plato used the analogy of our soul animating our body as its source of motion (Phaedrus 245 c). While the macrocosm is typically regarded as complete, orderly, perfect and immortal, the microcosmic parallel will be seen as more vulnerable, less perfect and in need of the ordering to be obtained by contemplation of its macrocosmic partner. ${ }^{60}$ Stoic use of arguments from correspondence between the visible cosmos as organic macrocosmic whole, with all living beings in it as its microcosmic parts, also accented the significance of members or parts of the universe, especially human beings, in 'following along' with the providential pattern given in the cosmos. The Hermetic literature, too, is marked by attention for analogy between the macrocosmic world of the heavens and nature, with the human as a microscosm, parallel in composition with respect to body, soul and spirit. ${ }^{61}$ Plotinus himself shows cognizance of this type of argument in his reference to each of us as an intelligible world, a kóøuos vonтós: iii 4 [15] 3.23, or at iii 3 [48] 6.23-39 where he discusses

For discussion of the earth on a human analogy see Seneca's Natural Questions III, 15, 1; see further Lawrence (2005) 3 b iv.

59) For a clear example from Plato's work see the argument for the orderly and intelligent system of the universe in the Philebus, where Plato presents the human being and universe both having a body and a rational soul: our human soul derives from the soul of the universe, just as the human body derives from body of universe (Phil. $28 \mathrm{~d}-30 \mathrm{~d}$ ). Just as our soul holds the body together, the universe has a soul holding everything together; and just as our soul is rational, the soul of the world has corresponding rationality, wisdom ( $\left.\sigma \circ \varphi^{i} \alpha\right)$ and intelligence (vovs, Phil. 30a). A similar discussion of the cosmos is given at Tim. 30, where Plato shows that it is endowed with soul and intelligence as image of the demiurge. 60) At Phaedrus 245c Plato affirms planets and stars as immortal and ensouled on the basis of the ordered regularity or rationality of their circuits, and because they are always in motion. Although macrocosmic elements are identical to those in us, they are pure, unmixed, and stronger in comparison with ours; as part, the microcosm is incomplete and more easily disturbed, and thus needs organs of sense and limbs for self-protection. On the basis of a correspondence with the macrocosmic universe, which governs the planets by reason, in an orderly fashion, the microcosm too is led to rule its emotions by reason to overcome inner dissension, and prepare the soul to return to the heavens as its origin (Timaeus 29d-47e).

61) On representative passages like the Poimandres 1, 12.31, see note 50 above. 
correspondence as basis of prophecy. ${ }^{62}$ It appears that he would limit the impact of such argumentation for magic, as also for sympathy, to the world of embodied reality.

\section{Signification and Freedom}

As noted above, sympathy functions as the common factor in prayer and magic, divination and astrology; Plotinus moves readily from one of these topics to the other. While the topics of prayer and magic remained peripheral to central argumentation, Plotinus devoted a number of treatises specifically to the practice and theory of astral divination; in each case the arguments about destiny, determinism, providence, and supposed evil intentions of divine celestial beings show Plotinus using positions that have further application for magic. From early essays like iii 1, we know that Plotinus did allow for a degree of causal influence from the cosmic circuit, the $\pi \varepsilon \rho \iota \varphi о \rho \alpha$, imparting growth, in sympathetic correspondence with heavenly bodies, ${ }^{63}$ though he gave the proviso that it is intended

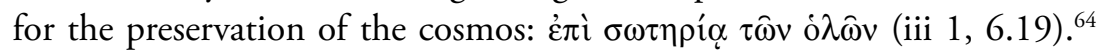
And the heavenly bodies in their positioning and arrangements may convey information, but not under compulsion of specific figures

62) One might go so far as to regard Plotinus' portrayal of universal, macrocosmic Nous and Soul, and even the One, on an analogy with the human being, as a unit(y) with individual mind and soul. For augury he says specifically, from analogy, that when the diviners or augurs see that birds are flying high, this may indicate heroic deeds (iii 1 [3] 6.19-24).

63) Plotinus is concerned that heavenly bodies not be considered malevolent, but he does allow for influence on growth of plants and animals (iii 1 [3] 5.9-10 and 6.5-8; also iv 4 [28] 31.25). With Plato he allows for influence from the stars in the descent of the individual soul into matter (see Timaeus 41a-42b), as cosmic deities add the lower embodied phase of soul, our temperament $(\eta \theta \eta)$ and emotions (ii 3, 9.1-14; also 15.13-17). Plotinus similarly recalls the Spindle of Fate of Plato's Republic 10, indicating that from the stars we

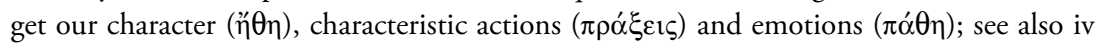
4, 31.25-30, on the action of heavenly bodies on our bodies and souls. But in accepting such influence he affirms that these causes are only one among many other influences.

64) The main points of the early discussion of fate or astrological determinism, iii 1 [3], are repeated in a late essay, ii 3 [52], and in the essays on providence iii 2 and iii 3 [47-48], where he deals with themes also important in the discussion of magic, for example the need for human initiative or free-will $(2,8-10)$, the cosmic drama $(2,18)$, and divination $(3,6)$. 


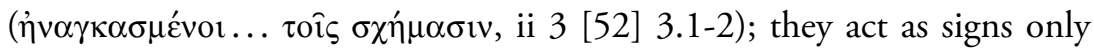
incidentally to their main function in the orderly arrangement $\left(\tau \alpha \xi_{1 \varsigma}\right)$ of the universe (ii 3, $7.4-9$, and 7.15-16). ${ }^{65}$ Plotinus compares this with the functioning of our eyes, which have vision as their primary function, but incidentally indicate character and personality, without being the cause of personality (ii 3, 7.8-9). The same point can be made from the analogy of the dance performance where individual gestures signify a meaning, not causally, but in a way that is incidental to the main function of the movements (iv 4, 33. 8-27).

The important argument in the background here is that of a connection between virtue and freedom. As Plotinus recalls repeatedly, 'virtue has no master' (ii 3, 9.18, citing Plato's Republic 617e3); virtuous deeds when performed under compulsion are not virtuous. This accounts in part for his emphasis on the role of what is peculiarly 'ours', especially the ability to control our emotions and passions, to exercise reason and make decisions; ${ }^{66}$ as a purification of the soul, virtue is the first requirement toward mystic union. And Plotinus repeatedly indicates that he is confident that the virtuous will receive the appropriate reward, while the wicked will receive their just punishment (iii 2 [47] 8-9). This is also the reason for his rather low evaluation of prayer (on which see further below); the soldier would do better to get training and act courageously,

65) Like omens provided by birds, the stars or planets signify and are suited for divination only because of sympathy: they are part of the cosmos in the whole of which all parts "breathe as one" ( $\left.\sigma \dot{\mu} \mu \pi v o 1 \alpha \mu \dot{i}^{\alpha} \alpha\right)$ and contribute to the harmony of the whole (ii 3 [52]

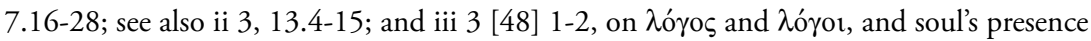
in all parts; further, iv 3 [27] 12.14-26; iii 1 [3] 6; iii 3 [47] 6; and ii 3, 7-8). Plotinus argues that birds of augury only give signs of what is to come; signification is incidental to their activity (ii 3, 3.27-28); birds do not cause what they indicate (iii 1, 5.36-37). He compares the patterns and arrangement of stars to letters written in the heavens ( $\gamma \rho \alpha \dot{\alpha} \mu \mu \alpha \tau \alpha \dot{\varepsilon} v$

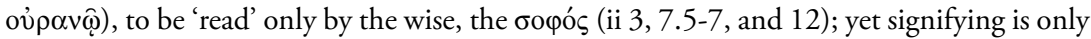
part of their work (see also iii 3, 6.19). Thus, if the configuration of the stars is recognized for signifying, this too is only incidental to their regular activity (ii 3, 3.27-28). Such arguments have implications for magic, since its operation too is based on sympathy, not on causality based on the heavenly bodies.

60) Even as Plotinus recognizes that the stars exert a degree of influence, he asks what is

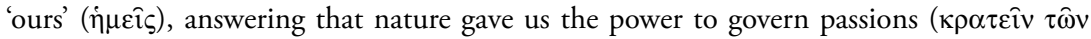
$\pi \alpha \theta \hat{\omega} v)$, make decisions, reason, and remain above, ii 3 [52] 9.14-18, also 15.14-17. See further iii 1 [3] 4 and 5.33, affirming that we need to resist lust ( $\dot{\pi} \pi \theta v \mu i ́ \alpha)$; we are capable of that when looking to what is best, above, ii 3, 9.13, and 39 . 
instead of praying to the gods for a successful battle, for they cannot give the impossible.

There are clear implications from such arguments regarding astral determinism and signification for Plotinus' appreciation of magic. He wants to assure a proper role for what is 'ours'; virtue would have no sense if all our actions might be predetermined, or determined by an external cause.

\section{The Divine Character of the Celestial Bodies}

Like prayer, the exercise of magic is directed to the deities which in the Hellenistic period were identified with the heavenly bodies, the moon, the sun, the planets, and even the stars. The fact that we may attribute to these a degree of perception, and that answers to prayers are received (not contested by Plotinus), motivates the significant discussion on memory, of which our passage (iv 4, 40-45) is the culmination. Plotinus acknowledged that inasmuch as the heavenly bodies are parts of the visible cosmic circuit, as embodied souls, they can be affected, and also respond to prayer or magical operations. The question which then becomes urgent, and is raised a number of times in the Enneads, is the character of influence of the heavenly bodies: is it valid to attribute to the cosmic deities a causality in inflicting harm, making them accomplices in thievery or slave-dealing?

Aside from an analysis of the source of evil in our world, which is implied in this question, it is important to recognize its motivation, namely the degree of popular fear aroused by the phenomena to which astrologists turn for divination and prediction (iv 4, 35. 50-54). Similarly, the degree to which many considered magical operation as a source of harm that could be inflicted on its object: sickness, or poverty (ii 3, 2; iii 1, 6.11). ${ }^{67}$

\footnotetext{
67) As he affirms (at ii 3 [52] 2.10-21; also iii 1 [3] 6.7-15), Plotinus is concerned about implications of astrological divination as it attributes evil to the circuit of stars, making it the cause of evil, sickness, ugliness, and poverty, and assigning responsibility to the stars for some being foolish while others are wise. The stars do have souls, and thus intentions may be attributed to them (ii 3, 2.17). But how can they bestow wicked character, he asks. As noted above, a strong basic appreciation of the divine determined Plotinus' conclusions on this matter.
} 
This aspect of the discussion should not be underestimated. ${ }^{68}$ Plotinus is aware that harm may befall, and magic may have something to do with it, as he acknowledges in iv 4, 44 on the sage who may be the victim of magic to the point of getting ill, or even death. Such fears are real, and justified. The kind of magic he has in mind, clearly, is not the benign or positive magic to which some might turn in desire for union with the divine, as it is known from magical papyri, and from Hermetic or Gnostic texts.

Plotinus' response to these fears is not to deny the harm, but to undercut the supposition that the divine celestial bodies are responsible for such harm. And he questions the extent to which men may be able to influence higher bodies, describing the Gnostics who think they can do so (ii 9, 14; possibly also at iv 4, 35), as audacious and arrogant. How can the lower affect the higher? But this is not only an issue of degree of power according to ranking in the hierarchy of being. The significant question is whether the lower is able to affect the higher to bring harm, or good, for that matter. Plotinus would have realized that if the lower can affect the higher power to receive benefits from that realm, one must expect that the lower would also be able to affect the higher power to inflict harm on its own behalf, or in its own interest. If magic or prayer can influence the gods above, intentionally, even in bringing good, these methods can also be employed for evil results. ${ }^{69}$

As noted above, Plotinus recognized that $\delta \alpha$ ínoves could be affected by magic (iv 4 [28] 30.30; iv 8 [6] 5.23). Even the wise man ( $\sigma \pi \mathrm{ov \delta} \alpha \hat{\mathrm{i} o \zeta)}$

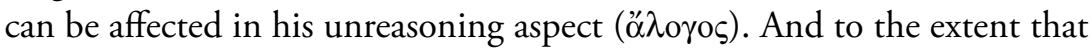
the heavenly bodies are just that, embodied souls and parts of the cosmic circuit in that way, characterized by perception, and able to answer prayer, they are parts within a larger whole, and must function within that larger context or $\sigma \nu v \tau \alpha \dot{\xi} \xi_{1 \varsigma}{ }^{70}$ Plotinus does recognize opposing elements there,

\footnotetext{
68) Alongside contempt, magic, astrology and divination inspired fear, as Plotinus reflects at iv 4 [28] 35.51-54; this is widely attested in the literature (see note 20 above). Plotinus realized that magic and divination were feared by those who might become the object of evil predictions.

69) This may well be why Plotinus affirmed the celestial gods, by definition, as $\alpha \pi \alpha \theta \dot{n} \varsigma$ and eternal; if they participate in matter, it is the very best air or fire. See iii 5 [50] 6.10, and 35-39.

70) As parts within a cosmic organic whole, the movements of the stars are guided by
} 
which function on a macrocosmic scale as does bile or $\theta \dot{u} \mu \mathrm{s} /$ passionate anger in us, as microcosm (iv 4, 32.25-30); and he affirms punishments and trouble as part of the universal order of things. ${ }^{71}$ If diviners foretell what is worse, however, it is to be attributed to the intertwinement of opposites within the composite living being, which necessarily includes the lower elements along with the higher (iii 3, 6.17ff.), ${ }^{72}$ though he affirms at the same time that their observations do not enable diviners to

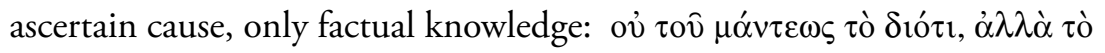

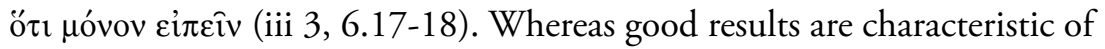
what we receive from the world above, Plotinus affirms in iv 4 [28] 38, that evil comes from a variety of causes, especially the inability of the substrate the receive what is good; but we should not attribute these to prayer or $\tau \varepsilon^{\prime} \chi v \eta$ of magicians (iv 4, 38.1-4). And we certainly should not attribute evil to the stars who, as $\theta$ coí, live a blessed life, for they are both eternal and $\dot{\alpha} \pi \alpha \theta n \varsigma$, consisting of the very best ingredients of air or fire (iii 5 [50] 6.10, and 35-39); located in a divine тó

universal soul, as part of a comprehensive principle of coordination a single comprehensive $\sigma 0 ́ v \tau \alpha \xi 1 \zeta$, which is also the basis for discerning signs from birds, or stars, divination (ii 3,7.15-28). See above notes 39 and 42.

71) He explains negative effects resulting in unpleasant $\pi \alpha \dot{\theta} \theta \eta \mu \alpha$ on the basis of 'dissimilarity' of an affecting cause, the hurtful action of one member affecting another (corresponding to bile or $\theta v \mu$ ó $\varsigma$ in us, iv 4, 32.25-30); 'similarity' of what is affecting and is affected does not cause an alien affection. Even so, he affirms that we are not to attribute such effects to deliberate choice or intention in the communication of power (iv 4, 37.18-26; again, on signification as not a matter of intention, at iv 4, 39.17-22). As he explains, the sympathetic effect in the answer to prayer seems to come through automatic type of reac-

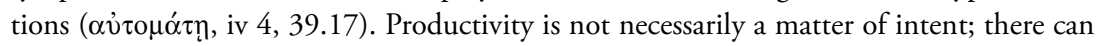
be efficiency of reproduction without will, accomplishing what is desired without selfconsciousness or memory (as in the propagation of a child); see on this also Rist (1967) 205.

72) The explanation given in iii 3 [48] 6.17-18 is one of the more extensive attempts to account for evil in the context of divination, recognizing that it may point to something that is evil (i.e. lower or worse, $\tau \grave{\alpha} \chi \varepsilon \varepsilon^{\prime} \rho \omega, 6.1$ ). This is because opposites are entwined in the composite living thing as form and matter, which includes what is lower (6.1-8); higher beings do give of themselves to the lower ( $\tau \hat{\text { ̣̣ } \chi \varepsilon ı \rho o ́ v ı, ~ i i i ~} 3$ [48] 7.5). Punishments and suffering are part of a universal order, $\tau \alpha^{\prime} \xi_{1 \varsigma}$ (iv 3 [27] 16.13-22). For the most part Plotinus accounts for inferiority in terms of the material aspect, though even here harmony can dominate conflict; providence does extend to the earth, and fate is a lower providence. But he insists on leaving room for initiative and individual free will (iii 1 [3] 5.21-24). 


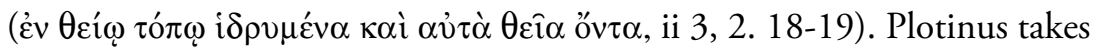
it to be axiomatic that as such they cannot be the cause of evil. Nor should they be regarded as changeable or capricious, introducing disorder into the cosmos, for their motions tend only to preservation of the cos-

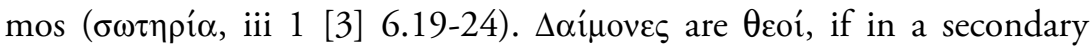
sense compared to stars and planets (iii 1 [3], 6.11); they too are not to be regarded as the source of harm, disease or wicked behaviour.

Just how does Plotinus come to such a conclusion, when in fact he acknowledges that $\delta$ aínoves can be affected, and that even the stars and planets, inasmuch as they are embodied (and are thus constituent parts of the cosmic circuit), can perceive and also answer prayer? The clue has to be found in his argument about memory in iv $3-4$, where he claims that the gods do not need it, anymore than they need organs for perception (as we do), or the ability to reason discursively and make calculations in directing the cosmos. ${ }^{73}$ They perform their work just as the World Soul does, without effort, and without intentionality or use of will. They answer prayer as an aspect of their incorporation within the cosmos, involved in sympathetic action and reaction within that context. So even answers that may be considered negative are not to be attributed to the will of the gods, but rather to a type of automatic reaction (iv 4, 39.17-18), just as we reproduce children without specific intention, or we may be charmed by the snake without perception of its effect on us, ö $\tau \alpha v$

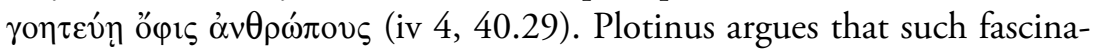
tion occurs without our awareness of it; the underlying cause, again, is sympathy (41.2). Plotinus emphasizes in that connection that the leading part of the universe, the $\dot{\eta} \gamma \varepsilon \mu$ ovov̂v (i.e. the World Soul), is $\dot{\alpha} \pi \alpha \theta \varepsilon \dot{\varepsilon}$; just as our soul too, with its highest part, does not descend, the World Soul

73) The argument concerning memory (iv 3,25 -iv 4, 12), affirms it as appropriate to the soul, particularly the image-making faculty (iv 3, 26 and 28-30). Heavenly bodies do not need memory, because they are not intentional in managing human affairs (iv 4, 6.14); their lives are blessed (8.53-62). Not even Zeus, as 'royal soul', needs memory, since he works without reasoning or calculation (11.13). If the heavenly bodies receive prayers or the effects of the arts of magicians, this is caused by sympathy (iv 4, 26.1-4). Resuming the issue of prayer at iv 4, 30, Plotinus reiterates that acts of memory are not necessary for stars, though they have perception, hearing and seeing; answer to prayer is a matter of sympathy, or the effect of like on like; if the whole cosmos is a single living being, with all parts connected, distance is no barrier. 
remains above and directs the cosmos in an effortless manner. Its highest part is transcendent, and completely immaterial (iv 4, 42. 19-23); and the same would certainly apply to the souls of the stars.

With this we come to an affirmation of the important role of the introductory chapters of the treatise iv 3-5, on the source of our souls, not in the World Soul, but in the one soul which is totally immaterial, the hypostasis, as source of both our soul and the soul of the world. Our souls thus remain intimately interconnected with the intelligible world, and we

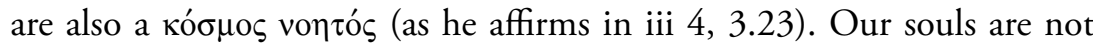
dependent on the World Soul in contemplation of the world above, and thus with our highest part we remain $\dot{\alpha} \pi \alpha \theta \dot{n} \varsigma$ and immune to that which pertains to the world in which sympathy is operative. This is the reason why Plotinus can affirm the sage, the $\sigma \pi$ ovodios, who lives at the level of reason or intellect, as ultimately not affected by magic, even though in his embodied state he suffers its consequences. Nor, on the other hand, should we think that he needs magic, or techniques like those of the magician, to attain to union; on the contrary, I believe it is a mistake to posit such a procedure of operation, for in his argumentation Plotinus consistently shows a negative attitude to such techniques, contrasting them disparagingly with the natural process, which works without intentionality, deliberation, or foresight. Magical techniques may have an impact on the world of physical reality, on our bodies, which represent the lower soul; but with the higher soul we are not subject to these techniques. In this respect the position of Plotinus would receive considerable modification from his successors, especially Iamblichus, who rejected the higher soul as undescended, and accordingly allowed far greater scope for the role of magic and theurgy. ${ }^{74}$

\footnotetext{
74) See Dillon (2005) 343-351 on the extended discussion of the issue in passages of Iamblichus' De anima preserved in Stobaeus' Anthology, and published more recently in Finamore and Dillon (2002). The soul's ontological status when incarnate, as clearly distinguished from what is intelligible, superior and impassive, is also discussed in Iamblichus' commentary on the Timaeus, particularly on Tim. 43c-d, a passage preserved by Proclus; on this passage see also Steel (1978) 38-39.
} 


\section{The Ascent of the Soul and Mystic Union}

Plotinus' origins were in Hellenistic Egypt, and his education from Alexandria, a centre of cultural and religious cross-currents of the ancient world; data from the Vita points to connections with Hellenized aristocratic circles there. Certainly, once he came to Rome in 244, he settled easily among citizens of the upper senatorial class, staying in the home of Gemina (VP 9), attracting students from various parts of the empire, the doctor Eustochius and Zethos from the east, but also from the senatorial class in Rome itself: Orrontius, Sabinillus, Rogatianus, even attracting the attention of the Emperor Gallienus $(V P 7,12)$. While not himself politically active, Plotinus' circle in Rome included prominent political figures. Assessment of his attitude to magic and astrology needs to keep in mind that in Rome magic was punishable by law, and noticeable interest in divination, especially when pursued on a private and individual basis, could arouse suspicion and prosecution; if not determinative for Plotinus' philosophical position, these contextual factors will have played a peripheral role. Similarly, Plotinus' appreciation for virtue as its own reward, while not out of line for Stoicizing Platonism, can be understood in terms of a politically prominent and responsible context.

Even so, we have noted an interesting elaboration of the magic of nature, enchanting souls to focus on externals. Eros is the master magician, a wizard and enchanter, drawing souls to get deeply involved in the world of embodiment, even at their own peril, as is illustrated in the metaphor of the steersman (iv 3, 19.23-28). Souls are attracted to their images, as in the mirror of Dionysus, reflected in matter and body. But the role of magical attraction does not stop at that level, with its negative aspect. Eros attracts us to what is beautiful; and beauty in this world has its source in the world above. And so Plotinus also alludes to the attraction with which Eros draws the soul upward, to the world of goodness and beauty, and ultimately to the One, beyond any beauty we can imagine here (v 3 [49] 17.15-38; a similar allusion is found at i 6 [1] 8), but he does not develop the role of enchantment at that level in these essays.

The ascent of the soul in mystic union involves a withdrawal from externals (i 6 [1] 7.36-39; and v 3 [49] 17.38). For the three stages of ascent: purification, illumination, and union, the foundational stage is one of attainment to virtue by discarding the passions, as if they were 
clothes no longer needed for the sacred rites (i 6, 7.6-8; see also ii 9 [33] 15.22-32). The second stage involves assimilation to intellect, to pure thought, becoming godlike and recognizing the forms as pure ideas

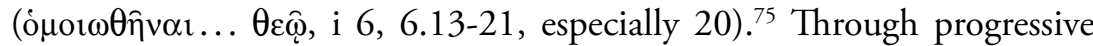
simplification, ascent finally takes us to the Good beyond all duality and otherness, and even beyond intelligible beauty, to the ultimate source

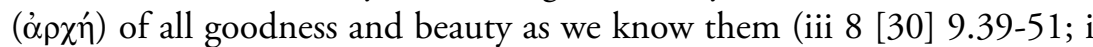
6, 7.8-12, and 9.42-44). This is as close as Plotinus comes to explaining the method by which we attain to mystic union, even speaking here of $\mu \eta \chi \alpha v \eta$ (i 6, 8.1); but as we examine the procedure of inner vision ("zv $\delta o v$

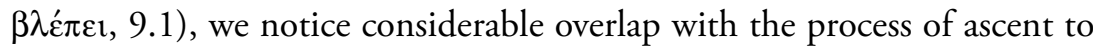
beauty in Plato's Symposium, as a matter of progressive abstraction. It is important to recognize, even so, that there is nothing secret about the process, nor does it require a specialist, or priest; it is a way of return open to all, even if it presents its own challenges, and not all can attain to union. Elsewhere Plotinus speaks of prayer to the god, and waiting, before taking a leap toward union as a kind of touching, vision, or presence of the One in an indescribably experience of union. ${ }^{76}$

Whether or not Plotinus intended to give more explicit instructions on how to attain to union, it is clear that the experience itself made a deep impression, confirming for him that the soul with its highest aspect remained undescended. It may well be that we have to take Porphyry at his word, explaining that Plotinus was a person with a special gift of insight, if not clairvoyance (VP 11). Mystic union was not something

\footnotetext{
75) See Rist (1967) 220-221.

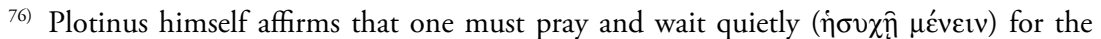
appearance of the One as one might wait for the rising sun (v 5 [32] 8.1-6). Nonetheless its appearance is sudden; the final stage toward union is described as something of a leap, or rushing (v 5, 4.8), also a grasping or touching of the One (бvvó $\pi \tau \varepsilon v / \sigma v v \alpha \varphi \eta$, vi 9 [9] 8.27; or $\lambda \alpha \beta \varepsilon i v, v 5,10.3)$; further, as a seeing, through awareness and reception

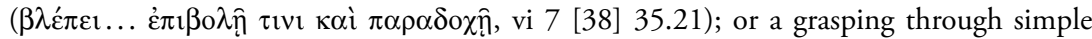

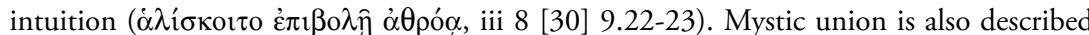

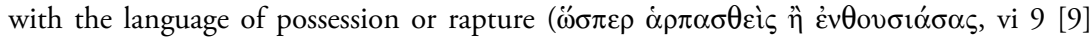

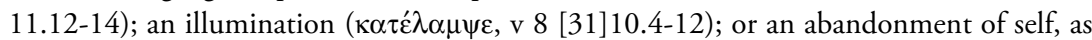
if being carried along by a wave or swell (vi 7, 36.18). A useful discussion of language for seeing the One can be found in Rist (1967) 217-222; on language for mystic union, see Rist (1967) 223-224.
} 
accomplished through elaborate technique; which did not prevent him from exploring its occurrence, reasons for its brevity, and ontological basis. It certainly gave him the basis for the argument which opens the treatise on the soul, iv 3-5, demonstrating that our soul finds its origin not in the World Soul, but shares a common origin with the World Soul in the one soul which remains transcendent, as soul-hypostasis, and does not as such belong with any particular body, universal or individual. This means that at every level of operation, our souls are (potentially) the equal of the World Soul, even if they are more vulnerable to the magic of nature. It also means that our souls are not necessarily at the mercy of cosmic forces or doínoves as these were presented in the cosmology popularized by Middle Platonists or Gnostics. For this reason, I would conclude, it is no coincidence that after dealing with embodiment, senseperception and memory (using iv 5 as an appendix to apply previously given principles to special problems of vision), Plotinus' discussion of the soul in iv 3-5 culminates with the treatment of magic and related phenomena.

\section{Bibliography}

Armstrong, A. H. trans. (1966-1988). Plotinus. The Enneads. 7 vols. Cambridge, MA: Harvard UP.

(1955). "Was Plotinus a Magician?” Phronesis 1, 73-79; reprinted in Plotinian and Christian Studies. London, 1979.

Berg (van den), R.-M. (1999). "Plotinus' attitude to traditional cult: a note on Porphyry VP 10" Ancient Philosophy 19.2, 345-360.

Betz, Hans Dieter (1992). The Greek Magical Papyri in Translation, Including the Demotic Spells. 2nd ed. Chicago: University of Chicago Press.

Brisson, Luc (1992). "Plotin et la magie", in Porphyre la Vie de Plotin. Etudes d'introduction, texte, traduction, commentaire et notes. Paris: J. Vrin. II, 465-475.

Broek (van den) R. and M. J. Vermaseren eds. (1981). Studies in Gnosticism and Hellenistic Religions. Leiden: E.J. Brill.

Copenhaver, Brian P. (1992). Hermetica: The Greek Corpus Hermeticum and the Latin Asclepius in a New English Translation. Cambridge, UK: Cambridge University Press.

Dickie, Matthew W. (2001). Magic and Magicians in the Greco-Roman World. London and New York: Routledge.

Dillon, John (2007). "Iamblichus' Defence of Theurgy: some Reflections" International Journal of the Platonic Tradition 1, 30-41.

(2005). "Iamblichus' Criticisms of Plotinus' Doctrine of the Undescended Soul" in Studi sull'anima in Plotino, Riccardo Chiaradonna ed. Naples: Bibliopolis, 337-351. 
(2002). "The Philosopher at Prayer" in Metaphysik und Religion, Akten des Internationalen Kongresses vom 13.-17. März 2001 in Würzburg. Theo Kobusch and Michael Erler, eds. Leipzig: K G Saur München, 279-295.

Dodds, E. R. (1951). "A Seance in the Iseum" in The Greeks and the Irrational (Appendix II, iii). Berkeley-Los Angeles: University of California Press, 289-291.

Edwards, M. J. (1991). "Two episodes in Porphyry's Life of Plotinus" Historia 40, 456-464.

Finamore, John F. (1999). "Plotinus and Iamblichus on Magic and Theurgy" Dionysius $17,83-94$.

- (1998). "Plotinus, Psellus, and the Chaldean Oracles: a reply to Majercik" Ancient World 29.2, 107-110; reply to Majercik (1998).

Finamore, John F. and John M. Dillon (2002). Iamblichus De Anima. Text, Translation and Commentary. Leiden: Brill.

Graf, Fritz (1996). La magie dans l'antiquité gréco-romaine. Paris: Belles Lettres.

- (2002). "Theories of Magic in Antiquity" in Paul Mirecki and M. Meyer eds. Magic and Ritual in the Ancient World. Leiden: Brill, 92-104.

Gurtler, Gary M. (2002). "Sympathy: Stoic Materialism and the Platonic Soul" in Neoplatonism and Nature. Michael F. Wagner, ed. ISNS vol. 3, Studies in Plotinus' Enneads. Albany, NY: SUNY Press, 241-276. This article reproduces almost exactly the third chapter in Gurtler (1988).

(1988). Plotinus. The Experience of Unity. New York: Peter Lang.

Hadot, P. (1982). 'L' 'amour magicien'. Aux origines de la notion de 'magia naturalis': Platon, Plotin, Marsile Ficin” Revue philosophique 172, 283-292.

Janowitz, Naomi (2001). Magic in the Roman World. Pagans, Jews and Christians. London and New York: Routledge.

Lawrence, Marilynn (2005). "Hellenistic Astrology" from The Internet Encyclopedia of Philosophy. http://www.iep.utm.edu/a/astr-hel.htm.

Lepajoe, M. (1998). "On the Demonology of Plotinus" in An Electronic Journal of Folklore vol.9, http://www.folklore.ee/folklore/vol9/plotinus.htm.

Lewy, Hans (1956). Chaldaean Oracles and Theurgy, Mysticism Magic and Platonism in the Later Roman Empire. Le Caire: L'Institut français d'archéologie orientale; nouvelle édition par Michel Tardieu, Paris: Etudes augustiniennes, 1978.

Luck, Georg (1985). Arcana Mundi: Magic and the Occult in the Greek and Roman Worlds: A Collection of Ancient Texts. Baltimore: The Johns Hopkins University Press.

Magesa, Laurenti (2008). "African Synod II and African Spirituality" St. Augustine University of Tanzania Service 7, 3-19.

Majercik, Ruth (1998). "The Chaldean Oracles and the School of Plotinus" Ancient World 29.2, 91-105.

—, ed. (1989). Julianus, the Theurgist. The Chaldaen Oracles: text, translation and commentary. Leiden: E.J. Brill.

Mazur, Zeke (2003)."Unio Magica: Part I: On the Magical Origins of Plotinus's Mysticism” Dionysius 21, 23-52.

- (2004). "Unio Magica: Part II: Plotinus, Theurgy, and the Question of Ritual" Dionysius 22, 29-55.

Merlan Ph. (1953). "Plotinus and Magic" Isis 44, 341-348. 
Nock, A.D. and A.-J. Festugière trans. (1954-1960). Hermetica. La révélation d'Hermes Trismégiste (Corpus Hermeticum). 4 vols. Paris: Belles lettres.

"Occultism" in the New Encyclopedia Britannica: Macropaedia. 15th ed. University of Chicago, 2010, Vol. 25.76-98.

Pigler, Agnès (2001). "La réception plotinienne de la notion stoïcienne de sympathie universelle" Revue de philosophie ancienne 19.1, 45-78.

Pliny the Elder (1940-63). Natural History (NH). H. Rackham, D.E. Eichholz, and W.H.S. Jones eds., trans. London: Heinemann.

Rappe, Sara (2000). Reading Neoplatonism: Non-discursive thinking in the texts of Plotinus, Proclus and Damascius. Cambridge, New York, Melbourne: Cambridge University Press.

Rist, John (1967). Plotinus: the Road to Reality. Cambridge, UK: University Press.

Robinson, James M. ed. (1977). The Nag Hammadi Library. NY: Harper \& Row.

Shaw, Gregory (1999). "Eros and Arithmos: Pythagorean theurgy in Iamblichus and Plotinus" Ancient Philosophy 19.1, 121-143.

- (1995). Theurgy and the Soul: the Neoplatonism of Iamblichus. Pennsylvania State University Press.

Smith, Andrew (2004). Philosophy in Late Antiquity. London and New York: Routledge.

- (1974). Porphyry's Place in the Neoplatonic Tradition: A Study in Post-Plotinian Neoplatonism. The Hague: M. Nijhoff.

Steel, Carlos (1978). The Changing Self. A Study on the Soul in Later Neoplatonism. Brussels: Paleis der Academiën.

Turner, John D. (2001). Sethian Gnosticism and the Platonic Tradition. Québec, Louvain; Paris: Presses Université Laval/Peeters, Bibliothèque copte de Nag Hammadi.

Wallis, R.T. (1983). "Plotinus and paranormal phenomena" in Essays in Ancient Greek Philosophy, J.P. Anton and A. Preus, eds. Albany, NY: SUNY Press, Vol. II. 495-507.

_ and Jay Bregman eds. (1991). Neoplatonism and Gnosticism. Albany NY: SUNY Press.

Wilberding, James (2006). Plotinus' Cosmology.A Study of Ennead II.1 [40]. Text, Translation, and Commentary. Oxford: University Press.

Yhap, Jennifer (2003). Plotinus on the Soul. A Study in the Metaphysics of Knowledge. Selinsgrove (PA): Susquehanna University Press; London: Associated University Presses. 